\title{
p38 MAPK Activation Promotes Denervated Schwann Cell Phenotype and Functions as a Negative Regulator of Schwann Cell Differentiation and Myelination
}

\author{
David P. Yang, ${ }^{1}$ Jihyun Kim, ${ }^{1}$ Neeraja Syed, ${ }^{1}$ Young-john Tung, ${ }^{1}$ Ambily Bhaskaran, ${ }^{3}$ Thomas Mindos, ${ }^{2}$ Rhona Mirsky, ${ }^{3}$ \\ Kristjan R. Jessen, ${ }^{3}$ Patrice Maurel, ${ }^{1}$ David B. Parkinson, ${ }^{2 *}$ and Haesun A. Kim ${ }^{1 *}$ \\ ${ }^{1}$ Department of Biological Sciences, Rutgers University, Newark, New Jersey 07102, 2 Peninsula Medical School, University of Exeter, Institute of Biomedical \\ and Clinical Sciences, Plymouth PL6 8BU, Devon, United Kingdom, and ${ }^{3}$ Department of Cell and Developmental Biology, University College London, \\ London WC1E 6BT, United Kingdom
}

Physical damage to the peripheral nerves triggers Schwann cell injury response in the distal nerves in an event termed Wallerian degeneration: the Schwann cells degrade their myelin sheaths and dedifferentiate, reverting to a phenotype that supports axon regeneration and nerve repair. The molecular mechanisms regulating Schwann cell plasticity in the PNS remain to be elucidated. Using both in vivo and in vitro models for peripheral nerve injury, here we show that inhibition of 38 mitogen-activated protein kinase (MAPK) activity in mice blocks Schwann cell demyelination and dedifferentiation following nerve injury, suggesting that the kinase mediates the injury signal that triggers distal Schwann cell injury response. In myelinating cocultures, p38 MAPK also mediates myelin breakdown induced by Schwann cell growth factors, such as neuregulin and FGF-2. Furthermore, ectopic activation of p38 MAPK is sufficient to induce myelin breakdown and drives differentiated Schwann cells to acquire phenotypic features of immature Schwann cells. We also show that p38 MAPK concomitantly functions as a negative regulator of Schwann cell differentiation: enforced p38 MAPK activation blocks cAMPinduced expression of Krox 20 and myelin proteins, but induces expression of c-Jun. As expected of its role as a negative signal for myelination, inhibition of $\mathrm{p} 38$ MAPK in cocultures promotes myelin formation by increasing the number as well as the length of individual myelin segments. Altogether, our data identify p38 MAPK as an important regulator of Schwann cell plasticity and differentiation.

\section{Introduction}

Schwann cells are a regenerative cell type, and their plasticity is essential for their function in facilitating nerve repair. Following nerve injury, Schwann cells distal to the injury site demyelinate and convert to a proliferative phenotype that shows similarities with immature Schwann cells, while also providing a strikingly growth-supportive environment that facilitates axon regrowth and remyelination. The molecular trigger that initiates the early components of the Schwann cell injury response, demyelination and dedifferentiation, is largely unknown; however, it is becoming increasingly clear that the signal is mediated by activation of intracellular signaling cascades and gene regulatory proteins.

\footnotetext{
Received Nov. 21, 2011; revised March 6, 2012; accepted March 29, 2012.

Author contributions: R.M., K.R.J., P.M., D.B.P., and H.A.K. designed research; D.P.Y., J.K., N.S., A.B., and T.M. performed research; P.M. contributed unpublished reagents/analytic tools; J.K. and Y.-j.T. analyzed data; H.A.K. wrote the paper.

This work was supported by grants from the National Institutes of Health (R01NS056135) and New Jersey Commission on Brain Injury Research to H.A.K.; a Wellcome Trust Program grant to K.R.J., R.M., and D.B.P.; and funding to K.R.J. and R.M. from the European Community's Seventh Framework Program (FP7/2007-2013) under Grant agreement No. HEALTH-F2-2008-201535.

*D.B.P. and H.A.K. are c0-senior authors.

Correspondence should be addressed to Haesun A. Kim, Rutgers University, Department of Biological Sciences,

Boyden Hall, Room 206, 195 University Avenue, Newark, NJ 07102. E-mail: haekim@andromeda.rutgers.edu.

D.P.Y.'s present address: Department of Cancer Biology, Dana-Farber Cancer Institute, Boston MA 02115.

DOI:10.1523/JNEUROSCI.5812-11.2012

Copyright $\odot 2012$ the authors $\quad 0270-6474 / 12 / 327158-11 \$ 15.00 / 0$
}

Among these, members of the mitogen-activated protein kinase (MAPK) family, including extracellular signal-regulated protein kinases (Erks) and c-jun N-terminal protein kinases (JNKs), have been shown to play a role in mediating the injury signal that initiates Schwann cell dedifferentiation process. These MAPKs also act as negative regulators of Schwann cell differentiation and myelination, thus facilitating the transition toward the immature phenotype (Harrisingh et al., 2004; Ogata et al., 2004; Parkinson et al., 2008; Syed et al., 2010).

The role of p38 MAPK, another member of the MAPK family, in regulating Schwann cell plasticity and development is less clear; however, previous studies have implicated its role in initiating the Schwann cell injury response: after nerve injury, p38 MAPK is rapidly activated in the distal Schwann cells, which induces expression of various injury-responsive genes (Myers et al., 2003; Zrouri et al., 2004). The role of p38 MAPK in regulating Schwann cell development has also been suggested. Fragoso et al. showed that p38 MAPK activation mediates laminin signaling in Schwann cells that regulate cell elongation and alignment along axons, a process prerequisite for myelination. Accordingly, inhibition of p38 MAPK blocks Schwann cell myelination in cultures (Fragoso et al., 2003). However, the direct role of p38 MAPK in regulating Schwann cell differentiation and myelination past the initial events of Schwann cell-axon alignment is unclear. In oligodendrocytes, p38 MAPK function is essential for oligodendro- 
cyte progenitor cell proliferation and lineage progression. The kinase also regulates oligodendrocyte differentiation by promoting myelin gene expression, indicating its role in regulating CNS myelination (Baron et al., 2000; Bhat et al., 2007; Fragoso et al., 2007; Chew et al., 2010).

In this study, we further investigate the functions of $\mathrm{p} 38$ MAPK in Schwann cells. We show that p38 MAPK mediates the Schwann cell injury response in vivo: inhibition of the kinase activity blocks demyelination in the distal nerves. We also show that p38 MAPK promotes Schwann cell dedifferentiation by downregulating myelin proteins and increasing expression of c-Jun, a transcription factor associated with the immature and denervated adult Schwann cell phenotypes. Furthermore, we provide evidence that $\mathrm{p} 38$ MAPK acts as a negative regulator of Schwann cell differentiation and myelination. Ectopic activation of the p38 MAPK pathway inhibits cAMP-induced Schwann cell differentiation and myelin gene expression. Finally, we show that inhibition of the kinase activity increases Schwann cell myelin formation in culture. These results demonstrate a distinct role of p38 MAPK in regulating myelination in the PNS.

\section{Materials and Methods}

Antibodies and growth factors. For immunofluorescence analysis, monoclonal antibody (SMI94) to myelin basic protein (MBP; Covance) was used at 1:500. Polyclonal antibodies to phospho-p38 MAPK (p-p38); Cell Signaling Technology) and neurofilament NF-M (Covance) were used at 1:400 and 1:1000, respectively. For Western blot analysis, monoclonal antibodies to phospho-Akt (Cell Signaling Technology) and polyclonal antibody to phospho-Erk1/2 (Promega) were used at 1:1000 and 1:5000, respectively. Polyclonal antibodies to Akt (Cell Signaling Technology) and Erk1/2 (Promega) were used at 1:1000 and 1:5000, respectively. Polyclonal antibodies to phosphor-p38 MAPK (Cell Signaling Technology), p38 MAPK (Cell Signaling Technology), and c-Jun (BD Bioscience) were all used at 1:1000. Periaxin antibody was a gift from Peter Brophy (University of Edinburgh, Edinburgh, UK) (Gillespie et al., 1994). Monoclonal antibodies to Flag (GenScript) were used at 1:1000. Recombinant human epidermal growth factor (EGF) domain fragments of neuregulin-1 (Nrg1) and fibroblast growth factor 2 (FGF2) and were purchased from R\&D Systems.

Culture media. Culture media used were as follows: NB media [neurobasal medium with B-27 supplement, $0.08 \%$ glucose, $1 \%$ glutamine, and $0.1 \mathrm{mg} / \mathrm{ml}$ penicillin/streptomycin, and $50 \mathrm{ng} / \mathrm{ml}$ nerve growth factor (NGF)]; NB-HS media [NB media further supplemented with $5 \%$ horse serum (Sigma) and NGF at a concentration of either 35 or 100 $\mathrm{ng} / \mathrm{ml}$ ]; C media [minimal essential medium (Invitrogen) supplemented with $10 \%$ fetal bovine serum (FBS), $1 \%$ glutamine, $0.4 \%$ glucose, 0.1 $\mathrm{mg} / \mathrm{ml}$ penicillin/streptomycin, and $50 \mathrm{ng} / \mathrm{ml} \mathrm{NGF]}$.

Schwann cell-DRG coculture. Schwann cells were prepared from sciatic nerves of newborn rats ( $2 \mathrm{~d}$ old $)$ as described previously (Brockes et al., 1979). For routine cultures, Schwann cells were grown in DMEM (Mediatech) with $10 \%$ FBS (Mediatech) supplemented with $10 \mathrm{ng} / \mathrm{ml} \mathrm{Nrg} 1$ and $2 \mu \mathrm{M}$ forskolin (Sigma-Aldrich). Cells between passages 2 and 5 were used in all experiments described. For dorsal root ganglion (DRG)-Schwann cell cocultures, dissociated DRG were prepared from embryonic day 15.5 (E15.5) rat embryos as described previously (Eldridge et al., 1987) and plated onto Matrigel (BD Biosciences)-coated $12 \mathrm{~mm}$ glass coverslips at a density of 0.8 DRG/coverslip. Five to six hours later, the cultures were flooded with NB media containing $15 \mu \mathrm{M}$ 5-fluorodeoxyuridine (FdUr) (Sigma-Aldrich) and uridine (Sigma-Aldrich). Cultures were maintained in the medium for an additional 3-4 $\mathrm{d}$ to remove proliferating non-neuronal cells, and then were switched to fresh medium without FdUr and a uridine mixture and maintained until the DRG axons reached the periphery of the coverslips. Subsequently, Schwann cells were plated onto the neurons at a density of 100,000 cells/coverslip in C media. Five to seven days later, $50 \mu \mathrm{g} / \mathrm{ml}$ ascorbic acid was added to $\mathrm{C}$ media to initiate myelination.

Establishment of Schwann cell-DRG compartmentalized coculture system. Dorsal root ganglion neurons were plated into the center chamber of compartmentalized chambers (Campenot chambers) (Campenot, 1982; Campenot and Martin, 2001), as described previously (Guertin et al., 2005), with the following modifications: on day 1 , five to six dissociated DRGs were plated into the center chamber in $35 \mu \mathrm{l}$ of NB-HS medium containing $100 \mathrm{ng} / \mathrm{ml} \mathrm{NGF}$ and $15 \mu \mathrm{M}$ FdUr. The same medium was used to fill the side chambers. On day 2, the spaces outside of the Teflon divider were filled with NB-HS medium containing $35 \mathrm{ng} / \mathrm{ml}$ NGF and $15 \mu \mathrm{M}$ FdUr. On day 5, fresh media without FdUr, containing 35 and 100 $\mathrm{ng} / \mathrm{ml}$ NGF were added to the center and the side chambers, respectively. Cells were maintained in this media for 2 weeks to allow axons to grow into the side compartments. After 2 weeks, Schwann cells were seeded onto axons in the side compartments at a density of 100,000 cells/compartment in $\mathrm{C}$ media. Five days later, myelination was initiated by supplementing $\mathrm{C}$ media with $50 \mu \mathrm{g} / \mathrm{ml}$ ascorbic acid (Eldridge et al., 1987). Cells were fed with fresh medium every other day. Within 4 weeks, unidirectional myelinated axons were formed along the tracks in the side compartments. Before use, chambers were subjected to a leak test by using a tracking dye for visual detection as described previously (Esper and Loeb, 2004). To induce demyelination, axons in side chambers were cut with a razor blade. For p38 MAPK inhibition, the myelinated axons were pretreated with SB203580 $(7.5 \mu \mathrm{M})$ (LC Laboratories) or the carrier DMSO for $1 \mathrm{~h}$, then the axons were cut. Axons were maintained in the same media for $24 \mathrm{~h}$ before they were fixed and immunostained for MBP.

Growth factor-induced demyelination. Twelve days after the initiation of myelination, DRG-Schwann cell cocultures were treated with $1 \mathrm{nM}$ EGF domain fragment of Nrg1 or FGF2, with forskolin (Sigma-Aldrich) for $36 \mathrm{~h}$ in $\mathrm{C}$ media, after which they were processed for immunocytochemistry (MBP) or collected into lysates for Western blot analysis.

Mouse sciatic nerve injury and tissue processing. Eight-week-old C57BL/6 female mice were anesthetized, and the sciatic nerves were exposed and transected at $\sim 0.5 \mathrm{~cm}$ distal to the sciatic notch. To examine the effect of p38 MAPK inhibition on Schwann cell demyelination, mice received daily injections (intraperitoneally) of SB203580 at $60 \mathrm{mg} / \mathrm{kg}$ starting from $24 \mathrm{~h}$ before the surgery. Three days later, mice were perfused, and the nerves were harvested and fixed in $4 \%$ paraformaldehyde overnight. The nerves were then cryoprotected in $30 \%$ sucrose for $2 \mathrm{~d}$ before they were mounted in OTC medium and processed for immunohistochemistry. All experiments were performed in accordance with the Rutgers, the State University of New Jersey, Institutional Animal Care and Use Committee guidelines.

Dedifferentiation of denervated Schwann cells. Schwann cells were purified from postnatal day $4(\mathrm{P} 4)$ rat sciatic nerve by trypsin/collagenase digestion followed by immunopanning using Thy1-coated cell culture dishes to remove contaminating fibroblasts. Cells were plated at a density of 5000 cells in a $15 \mu \mathrm{l}$ drop on laminin/poly-D-lysine-coated coverslips, as previously described (Parkinson et al., 2001). Time 0 controls were fixed $3 \mathrm{~h}$ after plating. Sister coverslips were topped up with defined medium alone (Jessen et al., 1994) or defined medium supplemented with neuregulin-1 $(20 \mathrm{ng} / \mathrm{ml})$ in the presence or absence of $10 \mu \mathrm{M}$ SB203580. Forty-eight hours later, coverslips were fixed in 4\% paraformaldehyde and immunolabeled with antibodies to periaxin. Percentages of positive periaxin cells are given relative to the number of positive cells at time 0 of the experiment. All experiments were performed in triplicate, and statistical analysis was performed using the Student's $t$ test.

Immunostaining on cells and sciatic nerve sections. Immunofluorescence staining for MBP was carried out as follows. Cocultures or frozen nerve sections were fixed in $4 \%$ paraformaldehyde for $20 \mathrm{~min}$. After washing three times with PBS, samples were permeabilized in ice-cold methanol for $25 \mathrm{~min}$ and then incubated in blocking solution (5\% normal goat serum prepared in PBS supplemented with $0.3 \%$ Triton X-100) for $1 \mathrm{~h}$ at room temperature. This was followed by incubation with MBP primary antibody prepared in blocking solution at $4^{\circ} \mathrm{C}$ overnight. After PBS washes, samples were incubated with Alexa Fluor 488-conjugated goat anti-mouse secondary antibody (Invitrogen) for $45 \mathrm{~min}$. Cell nuclei were stained with DAPI or DRAQ5. For phospho-p38 MAPK immunohistochemistry, nerve sections were blocked with $2 \%$ normal goat-serum with $0.3 \%$ Triton $\mathrm{X}-100$ for $1 \mathrm{~h}$ at room temperature, and incubated for $2 \mathrm{~d}$ at $4^{\circ} \mathrm{C}$ with anti-p-p38 antibody at 1:400 dilution, as described previously (Jin et al., 2003). Incubation with the secondary antibody was 
done as described above. Dual labeling for Flag and phalloidin was performed as follows. Cells were fixed in $4 \%$ paraformaldehyde for $10 \mathrm{~min}$, washed three times with PBS, and then incubated in blocking solution for $1 \mathrm{~h}$ at room temperature. Primary antibodies against FLAG and Alexa Fluor 488-conjugated goat antimouse secondary antibodies were applied and washed as before. After nuclei staining, cells were incubated in Alexa Fluor 546-conjugated phalloidin (Invitrogen), diluted 1:50 in blocking solution, for $30 \mathrm{~min}$. Immunolabeling with periaxin antibodies was performed as described previously (Parkinson et al., 2004).

SDS-PAGE and Western blot analysis. To prepare the cell lysates, cocultures were washed twice in PBS and then lysed in $300 \mu \mathrm{l}$ of ice-cold lysis buffer (20 mm Tris-HCl, pH 7.4, 1\% NP-40, 10\% glycerol, 2.5 mм EGTA, 2.5 mм EDTA, 150 mм $\mathrm{NaCl}, 20 \mu \mathrm{M}$ leupeptin, $10 \mu \mathrm{g} / \mathrm{ml}$ aprotinin, $1 \mathrm{~mm}$ PMSF, $1 \mathrm{~mm}$ sodium orthovanadate, and 10 mM sodium fluoride). Lysates were cleared by centrifugation for $15 \mathrm{~min}$ at $12,000 \times g$ at $4^{\circ} \mathrm{C}$, and the supernatants were collected. Thirtyfive micrograms of the total proteins were size fractionated via $10 \%$ SDS-PAGE and transferred onto PVDF membrane. After blocking in $5 \%$ milk, the membranes were incubated with appropriate primary antibodies prepared in TBST (TBS plus $0.1 \%$ Tween 20) containing $5 \%$ bovine serum albumin. After incubation with infrared-dye-conjugated secondary antibodies, the protein bands were visualized and quantified on the Li-Cor Odyssey imaging system.

Lentivirus transduction of Schwann cells. Constitutively activated MKK6 expression plasmid pcDNA3-Flag MKK6-Glu was obtained from Addgene. The transgene was inserted into the entry vector pEN_TTmcs (Addgene) via PCRgenerated XhoI/SpeI restriction sites. LR clonase II (Invitrogen) was then used to mediate recombination between the MKK6-Glu-containing entry vectors with pSLIK lentivirus vector (Shin et al., 2006). Lentiviruses were produced by transfecting $293 \mathrm{FT}$ cells $\left(6 \times 10^{6}\right.$ cells) (Invitrogen) with the following DNA constructs: envelop plasmid pMD2.G (7 $\mu \mathrm{g})$; packaging plasmid psPAX2 (14 $\mu \mathrm{g})$ (Addgene); and the lentivirus vector MKK6-Glu pSLIK $(55 \mu \mathrm{g})$. Forty-eight hours after transfection, supernatant was harvested and placed on Schwann cells (330,000 cells/infection) in the presence of EGF-domain neuregulin (20 $\mathrm{ng} / \mathrm{ml})$, Forskolin $(2.5 \mu \mathrm{M})$, and protamine (10 $\mu \mathrm{g} / \mathrm{ml})$. Sixteen hours after the infection, the viral supernatant was removed, and the Schwann cells were expanded in the presence of the growth factors. To induce the transgene expression, $1 \mu \mathrm{g} / \mathrm{ml}$ doxycycline (Clontech) was added to the culture media.

Quantification of demyelination and myelination. Schwann cell demyelination in cocultures was assessed as previously (Zanazzi et al., 2001; Guertin et al., 2005). After immunostaining for $\mathrm{MBP}, \mathrm{MBP}-$ positive $(\mathrm{MBP}+)$ myelin segments were examined by epifluorescence microscopy on a Nikon E800 microscope with a $40 \times$ objective. The levels of demyelination were determined by the percentage of $\mathrm{MBP}+$ myelin segments that show signs of myelin breakdown, such as beading and fragmentation of the internodes. The num-

A

$\mathrm{B}$
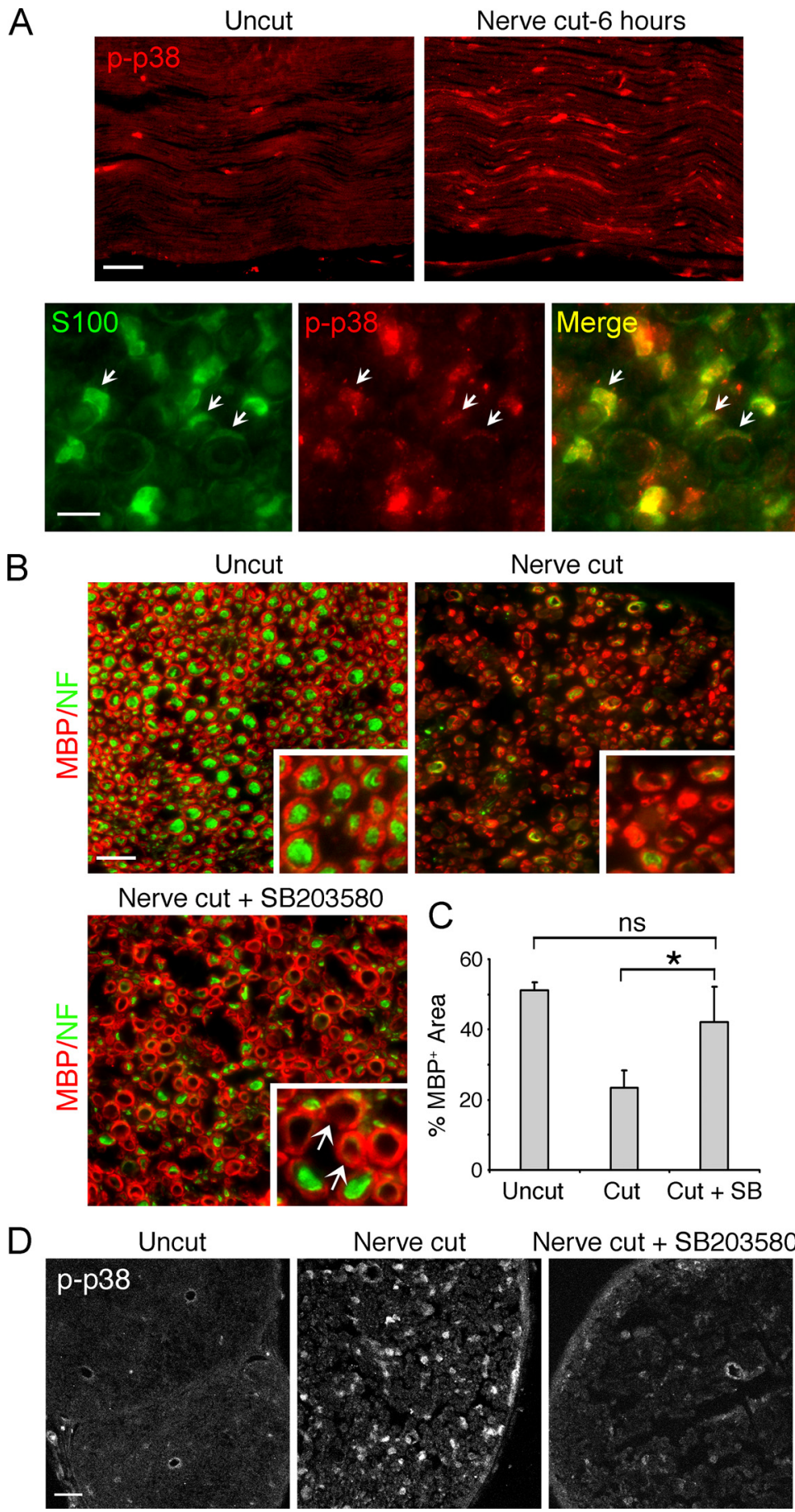

Nerve cut + SB203580

Figure 1. In vivo inhibition of $\mathrm{p} 38$ MAPK activity blocks Schwann cell demyelination in distal sciatic nerves following axotomy. $A$, Top Longitudinal sections of distal mouse sciatic nerve harvested $6 \mathrm{~h}$ after axotomy. Immunostaining for $\mathrm{p}$-p 38 shows activation of the kinase in the distal nerves. Scale bar, $50 \mu \mathrm{m}$. Bottom, Cross sections of the distal nerves $6 \mathrm{~h}$ postaxotomy coimmunostained with $\mathrm{S} 100$ (green) and phospho-p38MAPK. Activation of p38 MAPK is seen in S100 + Schwann cells, including the myelinating Schwann cells (arrows). Scale bar, $10 \mu \mathrm{m} . \boldsymbol{B}$, Cross sections of mouse distal sciatic nerves immunostained for MBP (green) and neurofilament (NF, red). Images taken at a higher magnification are shown in the insets. In normal nerves (uncut), $\mathrm{MBP}+$ myelin rings are visible, associated with NF + axons. Three days after nerve cut, myelin and the axons degenerate. Systemic injection of SB203580 inhibits myelin breakdown. Myelin rings without associated axons are shown (arrows). Scale bar, $20 \mu \mathrm{m}$. C, Quantification of the results shown in $\boldsymbol{B}$. Quantitative image analysis of the MBP + area, expressed as a percentage of the area within thenerve. ${ }^{*} p<0.05$. D, Cross sections of the distal sciatic nerves harvested 6 hafter axotomy. Systemic injection of SB203580 blocked p38MAPKactivation, visualized by immunostaining for phospho-p38MAPK. Scale bar, $50 \mu \mathrm{m}$. bers of normal and degenerating myelin segments were counted from 10 random fields selected across each coverslip, two coverslips per experiment from a total of three independent experiments. To determine the extent of demyelination in vivo, after immunostaining for MBP, epiflu- 
orescence images of transverse sections of mouse sciatic nerves were collected from three animals per condition. Using Image (NIH) software, MBP-positive areas were determined. To determine whether inhibition of $\mathrm{p} 38$ MAPK promotes myelination, cocultures were treated with SB203580 $3 \mathrm{~d}$ after the initiation of myelination. Six to seven days later, coverslips were fixed and processed for MBP immunofluorescence. The numbers of MBP-positive myelin segments were counted from individual fields imaged under a $10 \times$ objective. A total of 12-32 fields were imaged from each coverslip with four to five coverslips used per condition per experiment. Data were collected from three independent experiments. Myelin index values were determined as we have described previously (Syed et al., 2010). One-way ANOVA or Student's $t$ test was performed using SigmaStat 3.5 software.

\section{Results}

\section{p38 MAPK mediates Schwann cell demyelination during} Wallerian degeneration

Physical damage to peripheral nerves triggers myelin breakdown distal to the injury, a process termed Wallerian degeneration. Previous studies have shown that p38 MAPK is activated in the distal nerve stumps soon after nerve injury, suggesting that it may play a role in initiating the injury response (Myers et al., 2003; Zrouri et al., 2004; Yamazaki et al., 2009). To localize the source of early p38 MAPK activation, we performed immunostaining using activation state-specific antibody to p38 MAPK (p-p38 MAPK) on mouse distal nerve sections prepared $6 \mathrm{~h}$ after axotomy (Fig. $1 A$ ). The time point was chosen because at this early stage of Wallerian degeneration, the distal Schwann cells are yet to show any obvious signs of myelin breakdown. It is also unlikely that invading macrophages would be present in the distal nerves to contribute to the p38 MAPK activation. Following nerve injury, there was a drastic increase in phospho-p38 MAPK immunoreactivity in the distal nerves, in agreement with the previous reports (Fig. 1A). Double immunostaining on cross sections showed p38 MAPK activation in Schwann cells (S100 positive), including ones that appeared to be associated with single axons, indicating myelinating Schwann cells.

The Schwann cell-specific p38 MAPK activity at this stage suggests a role in initiating the Schwann cell injury response. If this is the case, inhibition of the injury-induced kinase activation should block myelin breakdown in the distal nerves. To block p38 MAPK activation in vivo, we used SB203580, a specific inhibitor of p38 MAPK (Cuenda et al., 1995). Systemic injection of SB203580 has been shown to block p38 MAPK signaling in vivo (Escott et al., 2000; Costantini et al., 2009). We injected adult mice with SB203580 and $24 \mathrm{~h}$ later injured the sciatic nerves by complete cut (i.e., axotomy). Control mice were injected with the carrier DMSO. After daily injections of the inhibitor for $3 \mathrm{~d}$, transverse distal nerve sections were prepared and demyelination was assessed by immunostaining for MBP (Fig. $1 B$ ). In normal sciatic nerves without injury (uncut), individual myelin units (MBP positive) were visible, each forming a 1:1 association with the axon (neurofilament positive). In injured nerves without the inhibitor, demyelination was clearly seen, as most of the myelin rings appeared collapsed and fragmented. Axon degeneration was also evident, as shown by the loss of the neurofilament staining. In SB203580-treated animals after injury, we observed that distal myelin rings were still visible without obvious signs of active demyelination. Image analysis showed that while there was an approximate $54 \%$ decrease in the $\mathrm{MBP}+$ area in control nerves after injury compared with the uncut nerve, indicating myelin loss, no significant decrease was seen SB203580 nerves postinjury (Fig. 1C). It was also interesting to note that the myelin rings in SB203580 nerves were often seen without the associated
A
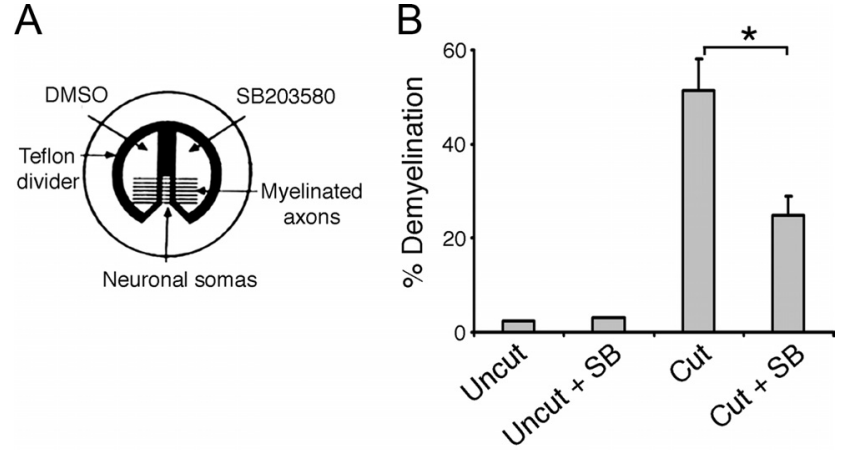

C
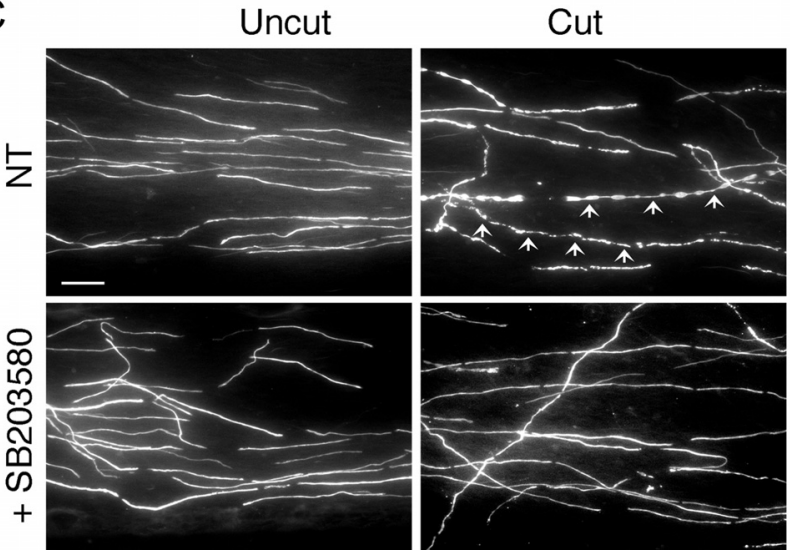

Figure 2. Inhibition of 38 MAPK blocks Schwann cell demyelination in compartmentalized myelinating cocultures. $A$, Schematic diagram of the compartmentalized coculture system. DRG neurons are plated in the center chamber after which the axons grow out to the side chambers while the cell bodies remain in the center. Schwann cells are added to the side chambers, which later form myelin on the axons. $\boldsymbol{B}$, Percentage of myelin segment undergoing demyelination after axotomy in the absence or in the presence of SB203580 (7.5 $\mu \mathrm{m}) .{ }^{*} p<0.001$. C, Images of the MBP-positive myelinated axons in the side compartments $24 \mathrm{~h}$ after axotomy. Degenerating myelin segments (arrows) are clearly seen on cut axons: myelin segments are fragmented or exhibit beaded morphology. SB203580 treatment inhibits axotomy-induced demyelination. Scale bar, $50 \mu \mathrm{m}$.

neurofilament-positive axons, indicating that the Schwann cells were able to retain the myelin despite the axon loss. SB203580 treatment did not affect the myelin integrity in normal nerves (data not shown), indicating that the basal level p38 MAPK activity was not required for the myelin maintenance. Immunostaining for phospho-p38 MAPK confirmed that the systemic injection of the inhibitor successfully blocked injury-induced p38 MAPK activation in the distal nerves (Fig. 1D).

Sciatic nerves contain other cell types including perineurial fibroblasts and endothelial cells. As mentioned above, macrophages also invade distal nerves to clear up myelin debris. To rule out the possibility that the inhibitory effect of SB203580 on demyelination was due to a secondary effect on other cell types, we conducted a similar experiment using our in vitro model for PNS nerve injury. As described in our previous report (Guertin et al., 2005), this culture system consists of only two cell types: DRG neurons and Schwann cells. However, unlike the conventional Schwann cell-neuron cocultures, the myelinated axons are established in side chambers separated from the neuronal somas in the middle, which allows a group of axons to be severed in synchrony (Fig. 2A). Furthermore, myelinated axons and the neuronal cell bodies render themselves separately to pharmacological and genetic manipulations. We pretreated myelinated axons on one side with SB203580 and the ones on the control side with DMSO. 
Forty-eight hours after severing the axons, demyelination was assessed by immunostaining for MBP. In the control side after axotomy, the MBP + myelin segments appeared beaded and fragmented, indicating myelin degeneration (Fig. 2C). The percentage of degenerating myelin was $52 \%$ compared with the basal level (2$3 \%$ ) seen in the absence of axotomy (Fig. $2 B)$. In the presence of the p 38 MAPK inhibitor, only $23 \%$ of the myelin segments showed signs of demyelination, such as beading and fragmentation, indicating that p38 MAPK inhibition attenuated the axotomy-induced myelin breakdown. SB203580 treatment on neuronal cell bodies in the center chamber had no effect on demyelination (data not shown), suggesting that the injury-induced neuronal p38 MAPK activity (Kim et al., 2002) did not contribute to the Schwann cell response. These experiments show that Schwann cell p38 MAPK activity plays a direct role in initiating injury-induced demyelination.

\section{p38 MAPK mediates growth}

\section{factor-induced demyelination}

The Schwann cell mitogen neuregulin has been implicated in initiating Schwann cell demyelination: it triggers myelin breakdown when added to Schwann cell-DRG cocultures (Zanazzi et al., 2001). Furthermore, inhibition of the receptor erbB2 activity blocks injury-induced demyelination both in vivo and in vitro (Guertin et al., 2005). Since the experiment above showed that $\mathrm{p} 38$ MAPK mediates injury-induced Schwann cell demyelination, we investigated whether the kinase function is involved in neuregulin-induced demyelination in cocultures. Fully myelinated cultures that had been preincubated with SB203580 were treated with neuregulin 1 (the EGF domain of neuregulin 1), and demyelination was assessed $48 \mathrm{~h}$ later. Figure $3 \mathrm{~A}$ reveals that neuregulin-induced demyelination was significantly decreased in the presence of the inhibitor. Corresponding immunoblots show the specificity of SB203580 on neuregulin-induced p38 MAPK activity but not on other kinases such as Akt, Erk, and JNK (Fig. 3B). This is important since neuregulin-induced Erk activation has been shown to trigger Schwann cell demyelination (Harrisingh et al., 2004).

FGF2 is another growth factor that stimulates Schwann cell proliferation. Unlike neuregulin, however, it requires an increase in intracellular CAMP to elicit the biological effect (Davis and Stroobant, 1990). We observed that FGF2, when combined with forskolin, also elicited a degenerative effect on the Schwann cell myelin (Fig. 3B) in cocultures. As seen with neuregulin, FGF2-induced demyelination was blocked by SB203580. Representative images of FGF2-treated cocultures are shown in Figure 3C. Altogether, these results show that p38 MAPK activity mediates growth factor-induced Schwann cell demyelination.

\section{Inhibition of p38 MAPK blocks Schwann cell dedifferentiation}

After Schwann cells lose contact with the axons after injury, they downregulate myelin proteins and re-express genes associated with the immature state. Since the Schwann cell p38 MAPK ac-
B

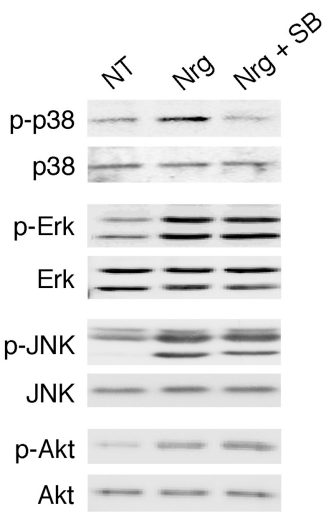

NT

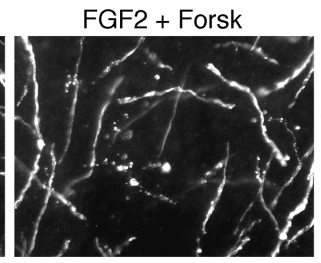

FGF2 + Forsk +SB

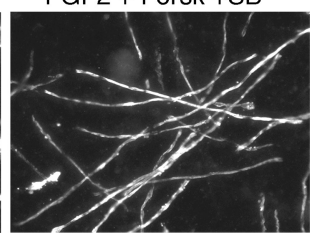
whether the kinase plays a role in promoting Schwann cell dedifferentiation. When Schwann cells are dissociated from nerves and plated in cultures, they spontaneously dedifferentiate in the absence of the axon contact, which can be detected by the loss of the myelin phenotype (Parkinson et al., 2008). Immunostaining for myelin protein periaxin showed that while $\sim 34 \%$ of the denervated Schwann cells expressed periaxin at the time of plating $(0 \mathrm{~h})$, the percentage decreased to $3.05 \%$ after being maintained in defined media for $48 \mathrm{~h}$, indicating that most of the Schwann cells dedifferentiated over time (Fig. 4). In the presence of neuregulin, the dedifferentiation process was further accelerated, as reported previously. When denervated Schwann cells were maintained in the presence of a p38 MAPK inhibitor, a significant number of Schwann cells (15.8\%) retained periaxin expression at $48 \mathrm{~h}$, indicating that inhibition of the kinase activity attenuated Schwann cell dedifferentiation. The p38 MAPK inhibition was also effective in blocking periaxin downregulation in neuregulintreated cultures: $20.7 \%$ of cells remained periaxin positive compared with $1.2 \%$ in the absence of the inhibitor. A similar result was shown in the corresponding Western blot analysis. An identical effect of p38 MAPK inhibition in maintaining the myelinating phenotype of Schwann cells in vitro was also seen with the myelin protein P-zero (data not shown). These results indicate that p38 MAPK plays an essential role in promoting Schwann cell dedifferentiation.

Activation of MKK6 is sufficient to initiate Schwann cell demyelination and dedifferentiation

So far, our data demonstrate that inhibition of p38 MAPK blocks Schwann cell demyelination and dedifferentiation. Next, we investigated whether p38 MAPK activation is sufficient to initiate the processes. Our strategy was to express a constitutively active 
form of MKK6 (MKK6-Glu), a direct and specific upstream activator of p38 MAPK (Enslen et al., 1998, 2000), in fully myelinated or differentiated Schwann cells. To ensure that MKK6-Glu expression did not interfere with the normal differentiation program (see Fig. 6), we infected Schwann cells with lentiviruses harboring MKK6-Glu under the control of a doxycyclineinducible promoter. The immunoblot in Figure $5 \mathrm{~A}$ shows that the addition of doxycycline to the culture media induced MKK6Glu (Flag+) expression and was sufficient to induce p38 MAPK activation in infected Schwann cells. To determine whether p38 MAPK triggers demyelination, we established myelinating cocultures using control or MKK6-Glu Schwann cells in doxycyclinefree media. After the axons were fully myelinated, Schwann cell p38 MAPK was activated by doxycycline and demyelination was assessed $48 \mathrm{~h}$ later. As shown in Figure $5 B$ extensive demyelination occurred in MKK6-Glu cultures in a doxycycline-dependent manner. In control noninfected cultures, doxycycline did not affect the myelin. Representative images of the cultures are shown in Figure $5 C$.

Next, we assessed the effect of MKK6-Glu expression on differentiated Schwann cells. Cultured Schwann cells differentiate to a myelinating phenotype when exposed to agents that increase intracellular cAMP. As shown in Figure 5D, after db-cAMP treatment for $3 \mathrm{~d}$, most of the Schwann cells acquire flattened morphology, which is distinguished from the spindle-shaped nondifferentiated Schwann cells. They also express myelinrelated proteins such as MAG and Krox 20 while downregulating immature Schwann cell markers such as c-Jun (Fig. 5E). To determine whether p38 MAPK activation is sufficient to drive Schwann cell dedifferentiation, MKK6-Glu Schwann cells were first differentiated with db-cAMP for $3 \mathrm{~d}$, then treated with doxycycline. Images show a drastic change in cell shape in MKK6-Gluexpressing Schwann cells (Flag positive), which reverted back to the nondifferentiated phenotype. All of the Flag-positive cells exhibited the nondifferentiated morphology indicating that $\mathrm{p} 38$ MAPK activation drove Schwann cell dedifferentiation with high efficiency. Flag-negative cells within the same culture maintained the flattened, differentiated morphology. The Schwann cells also lost MAG and Krox 20 expression upon MKK6-Glu expression but reacquired c-Jun, indicating that they dedifferentiated to the immature phenotype. Altogether, these experiments show that p38 MAPK activation is sufficient to trigger Schwann cell demyelination and dedifferentiation.

\section{p38 MAPK is a negative regulator of Schwann cell differentiation and myelination}

So far, our data suggest that p38 MAPK activation promotes the denervated Schwann cell phenotype. To determine whether the kinase activity is developmentally regulated during Schwann cell differentiation in vivo, we determined the activation levels of $\mathrm{p} 38$ MAPK in embryonic and postnatal rat sciatic nerves by Western blot analysis (Fig. 6A). The kinase activity was high in E17 nerves then dropped postnatally at $\mathrm{P} 1$, coinciding with the transition of immature Schwann cells to the myelinating phenotype. The activity continued to decrease as the myelination continued and was barely detectable in mature nerves. This observation along with the data above led us to hypothesize that p38 MAPK may act as a negative regulator of Schwann cell differentiation and the myelin program. We tested the hypothesis by determining whether ectopic p38 MAPK activation is sufficient to block Schwann cell differentiation and myelin gene expression induced by cAMP. MKK6-Glu Schwann cells were treated with doxycycline to activate p38 MAPK then differentiated by exposing them
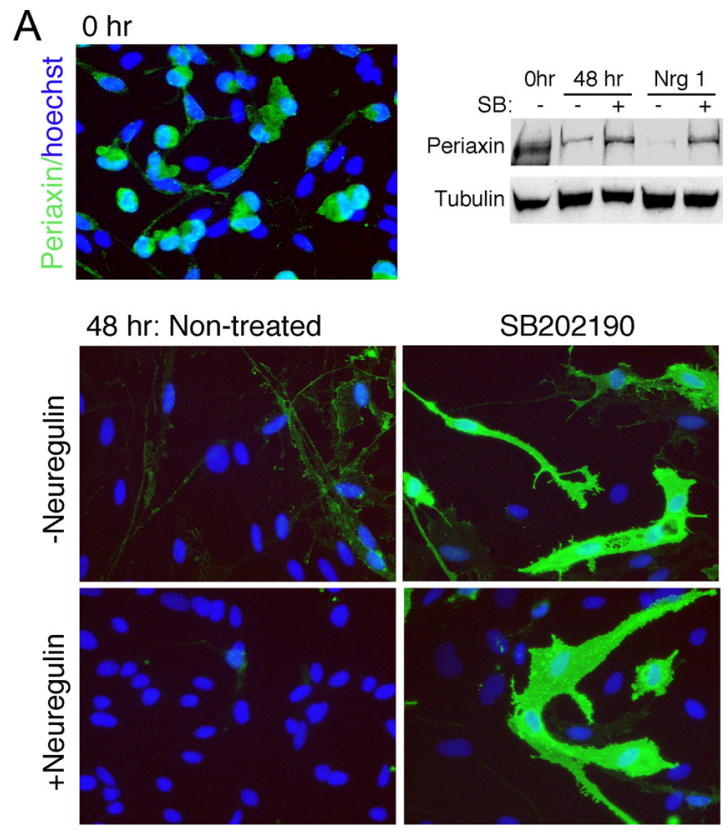

B

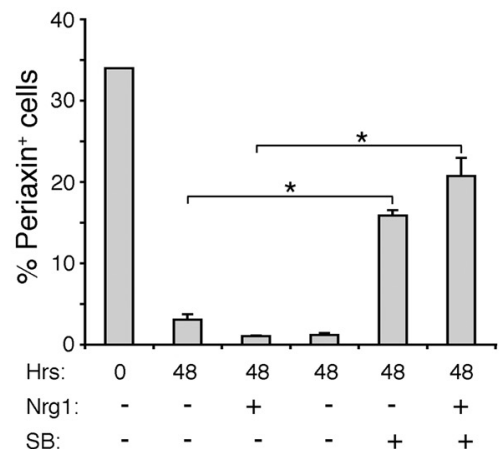

Figure 4. Inhibition of p38 MAPK blocks dedifferentiation of denervated Schwann cells. $\boldsymbol{A}_{\text {, }}$ Schwann cells from $\mathrm{P} 4$ rat sciatic nerves were immunostained for periaxin $3 \mathrm{~h}$ after plating on coverslips after digestion of the nerves (Time $0 ; 0 \mathrm{~h}$ ) or $48 \mathrm{~h}$ later. A decrease in the periaxin immunoreactivity is seen at $48 \mathrm{~h}$ compared with the time 0 control. Neuregulin facilitates the dedifferentiation process. Treatment with SB202190 $(10 \mu \mathrm{M})$ blocks the loss of periaxin even in the presence of neuregulin $(20 \mathrm{ng} / \mathrm{ml})$. Corresponding Western blot is shown on the top right. $B$ Quantification of the results presented as the percentage of periaxin-positive cells. ${ }^{*} p<0.005$.

to db-cAMP for $3 \mathrm{~d}$. Control cultures were treated with db-cAMP in the absence of doxycycline. Control Schwann cells exhibited the characteristic differentiated morphology and upregulated MAG and Krox 20 as expected (Fig. $6 B$ ). In the presence of doxycycline, which induced MKK6-Glu expression, the Flag-positive Schwann cells failed to adopt the differentiated morphology while the Flag-negative cells within the same culture differentiated normally. Schwann cells also failed to express MAG and Krox 20 when MKK6-Glu was expressed (Fig. 6C). This result indicates that ectopic activation of p38 MAPK inhibits Schwann cell differentiation.

If p38 MAPK functions as a negative signal for myelination, inhibition of the activity is expected to promote Schwann cell differentiation associated with the myelin phenotype. To test this, we first examined the effect of p38 MAPK inhibition on cAMPinduced Krox 20 expression. In control cultures, Schwann cells exhibited a dose-dependent response to db-cAMP: $\sim 0.9 \%, 16 \%$ and $79 \%$ of the Schwann cells were Krox 20 positive when exposed to $0.05,0.1$, and $1 \mu \mathrm{M} \mathrm{db}$-cAMP, respectively. Cotreatment with SB203580 enhanced the differentiation effect, with the most dramatic increase seen under the low dose $(0.05 \mathrm{mM})$ of cAMP 
(Fig. 7A). A similar result was obtained when Schwann cell differentiation was assessed by the periaxin expression (Fig. 7B). The corresponding Western blot shows the increase in Krox 20 and periaxin protein levels when low cAMP $(0.05 \mu \mathrm{M})$ was combined with p38 MAPK inhibition (Fig. 7C). Double immunostaining images in Figure $7 D$ indicate that induction of Krox-20 was accompanied by downregulation of c-Jun, an expected result if nondifferentiated Schwann cells were transitioning into the myelin phenotype (Fig. 7D) (Parkinson et al., 2008). SB203580 treatment alone, in the absence of db-cAMP, was not sufficient to induce the myelin-associated proteins or downregulate c-Jun (data not shown). This experiment demonstrates that inhibition of the basal p38 MAPK activity is sufficient to promote CAMP-induced Schwann cell differentiation.

Next, we investigated whether p38 MAPK inhibition promoted Schwann cell myelination in cocultures. A previous study has shown that p38 MAPK mediates ascorbic acid-induced laminin signaling in Schwann cells. Thus, when inhibited, it disrupts the basal lamina deposition and interferes with the Schwann cell alignment along the axons, steps that are a prerequisite for myelination (Fragoso et al., 2003). Therefore, to determine the effect on myelination without affecting these early steps, we first maintained the cocultures in normal myelinating media to allow the initial Schwann cell-axon interaction to occur. After 3 d, cultures were treated with SB203580 and myelination was assessed 6-7 d later. Data collected from three independent experiments showed that SB203580 treatment significantly increased the formation of myelin segments in a dose-dependent manner (Fig. 7E). We also observed that the average length of myelin segments was slightly longer by $10-11 \%$ when p38 MAPK was inhibited compared with the control Cocultures (Table 1). Western blot analysis showed that the decrease in p38 MAPK activity in cocultures was accompanied by an increase in the expression of MAG, a myelin-related protein (Fig. 7F). Altogether, these results strongly support the notion that p38 MAPK functions as a negative regulator of Schwann cell differentiation and myelination.

\section{Discussion}

The Schwann cell plasticity is essential for nerve regeneration and repair in the PNS. However, the molecular mechanisms governing the process still remain to be elucidated. In this study, we show that p38 MAPK activation in distal Schwann cells mediates the nerve injury signal that triggers demyelination. We also show that the kinase drives Schwann cell dedifferentiation by downregulating myelin proteins and inducing c-Jun, a transcription Nondifferentiated.
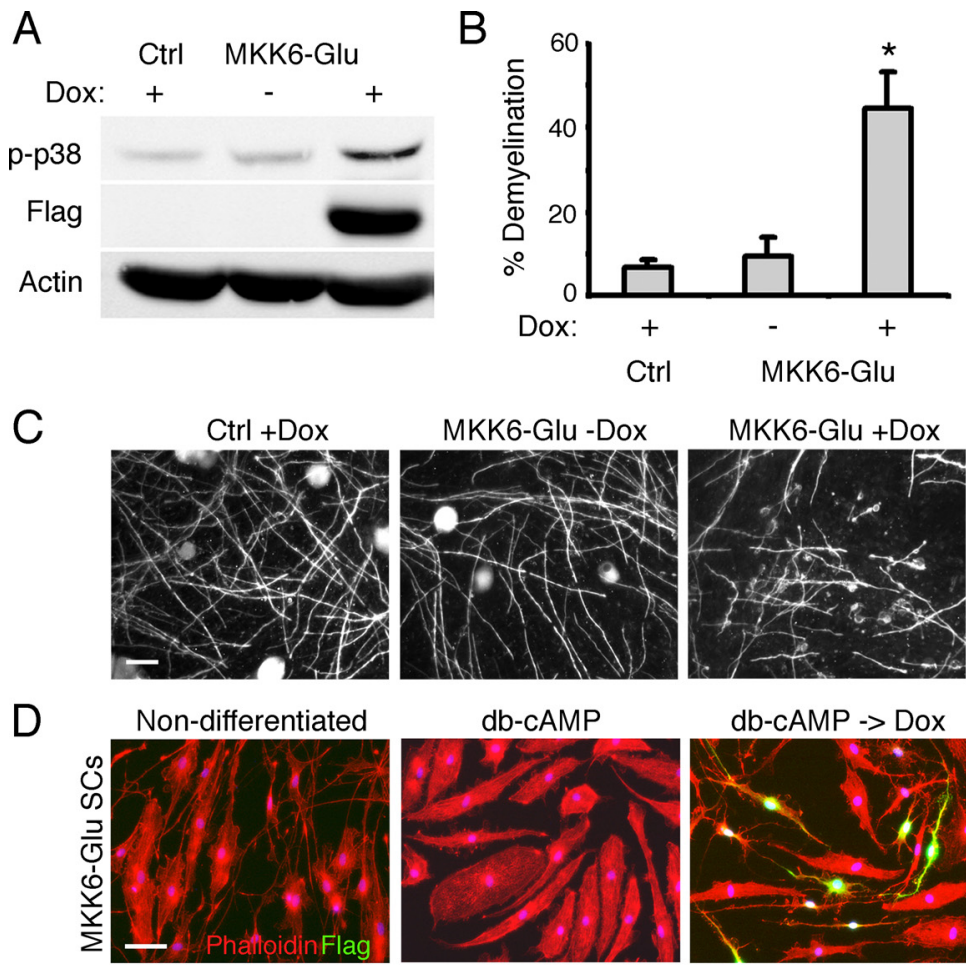

Figure 5. Activation of MKK6 is sufficient to induce Schwann cell demyelination and dedifferentiation. A, Schwann cells infected with lentiviruses encoding constitutively active MKK6 mutant (Flag positive) express the transgene upon treatment with doxycycline. Concomitant activation of p 38 MAPK is seen in the Schwann cells. B, Ectopic activation of p38 MAPK by doxycyclineinduced MKK6-Glu expression is sufficient to trigger $S$ chwann cell demyelination in cocultures. ${ }^{*} p<0.001$. C, Images of myelinating cocultures established using control or MKK6-Glu Schwann cells. Myelin degeneration is evident in MKK6-Glu cultures in the presence of doxycycline. Scale bar, $50 \mu \mathrm{m} . \boldsymbol{D}$, In the absence of doxycycline, MKK6-Glu Schwann cells were treated with db-CAMP for $3 \mathrm{~d}$ to induce differentiation. The differentiated Schwann cells (db-cAMP) exhibited the characteristic flattened morphology visualized by the labeling for actin (phalloidin red). Expression of MKK6-Glu (Flag positive, green) in the differentiated Schwann cells reverted the Schwann cells back to the undifferentiated morphology $24 \mathrm{~h}$ after the doxycycline treatment (db-CAMP + Dox). Scale bar, $50 \mu \mathrm{m}$. $\boldsymbol{E}$, Corresponding Western blot analysis. Upon p38 MAPK activation, induced by MKK6-Glu expression, the differentiated Schwann cells downregulated myelin proteins (MAG and Krox 20) while re-expressing c-jun. Non-diff,
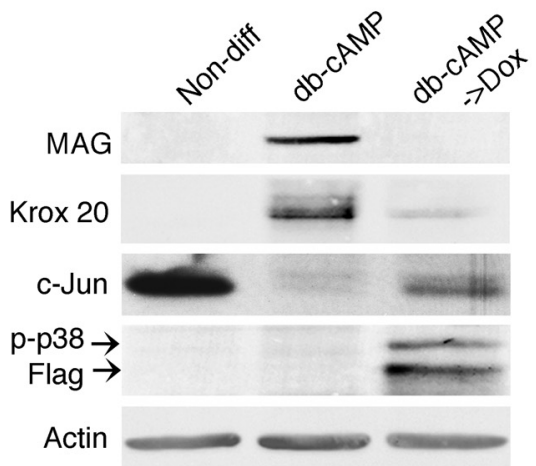

factor associated with immature Schwann cell phenotype. Last, we provide evidence that $\mathrm{p} 38 \mathrm{MAPK}$ acts as a negative regulator of Schwann cell differentiation and myelination. Altogether, this study identifies p38 MAPK as an important signal mediator that promotes the denervated state of Schwann cells.

Previous studies have shown that injury to the PNS induces rapid and sustained activation of $38 \mathrm{MAPK}$ in the distal nerves, indicating its involvement in Wallerian degeneration (Myers et al., 2003; Zrouri et al., 2004). Myers et al. (2003) reported Schwann cell-specific p38 MAPK activation in sciatic nerves $4 \mathrm{~d}$ after injury and suggested that the kinase plays a role in mediating the cytokine signaling in the distal Schwann cells. In the present study, we show that Schwann cell 
A

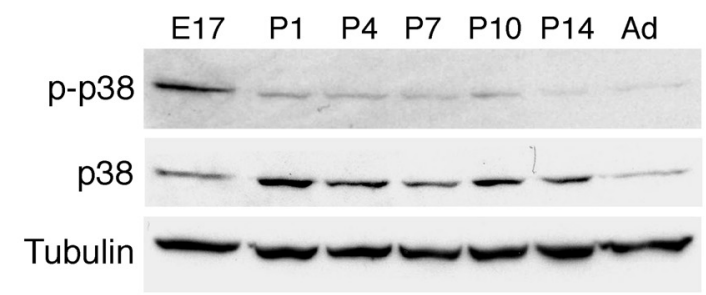

B
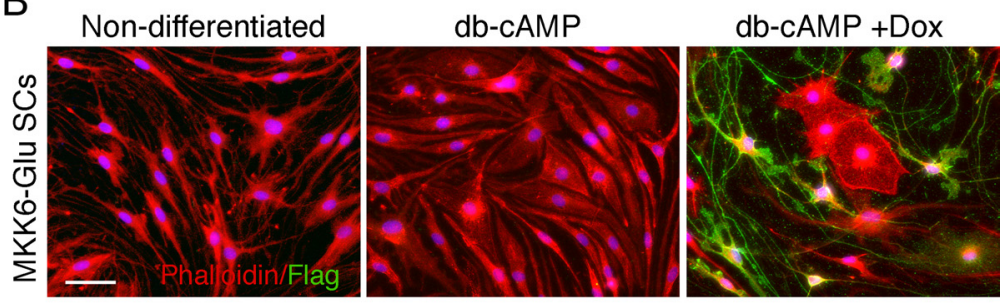

C
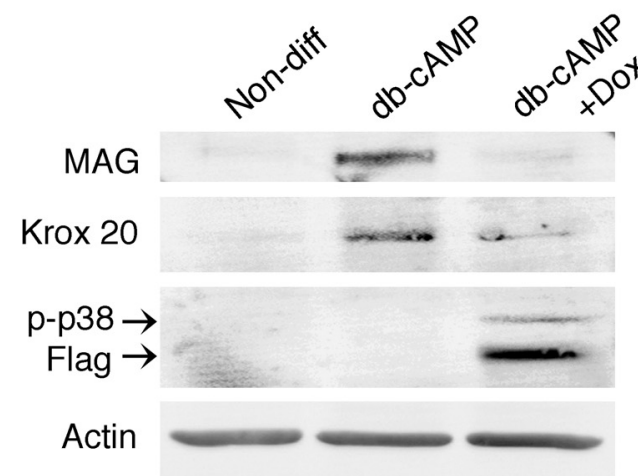

Figure 6. Ectopic activation of $\mathrm{p} 38 \mathrm{MAPK}$ blocks Schwann cell differentiation. $\boldsymbol{A}$, The levels of active p38 MAPK in developing rat sciatic nerves collected at E17, P1, P4, P7, P10, and P14, and in adult (Ad) animals. B, MKK6-Glu Schwann cells were differentiated with $\mathrm{db}$-cAMP for $3 \mathrm{~d}$ in the presence or in the absence of doxycycline. The MKK6-Glu-expressing Schwann cells (Flag positive, green), failed to acquire the differentiated morphology visualized by actin labeling (phalloidin, red). C, Corresponding Western blot analysis. In the presence of doxycycline, db-CAMP-treated MKK6-Glu Schwann cells failed to express proteins (MAG, Krox 20) associated with the differentiated phenotype.

p38 MAPK activity is detected much earlier, only a few hours after nerve injury and the systemic inhibition of the kinase attenuates injury-induced demyelination. These results indicate that p38 MAPK plays an essential role in initiating the early Schwann cell injury response. Use of the compartmentalized myelinating coculture system also allowed us to investigate the Schwann cellautonomous function of $338 \mathrm{MAPK}$. Because the in vitro system is established using only two cell types, Schwann cells and DRG neurons, we were able to exclude the possibility that p38 MAPK activity may be elicited by other cell types in the nerves or by cytokines released from the circulation after nerve damage. Although this does not rule out the axonal contribution of the active p38 MAPK, we further demonstrated that p38 MAPK activation in Schwann cell is sufficient to induce demyelination.

The injury-induced upstream signal that activates p38 MAPK in Schwann cells is unknown. In mammalian cells, p38 MAPK is activated by cytokines and growth factors (Paul et al., 1997). After nerve injury, distal Schwann cells produce cytokines and growth factors as they dedifferentiate and proliferate (Tofaris et al., 2002). Invading macrophages also release proinflammatory cytokines. However, as mentioned above, p38 MAPK activation in Schwann cells occurs immediately following injury, placing the event much earlier than the period of cytokine release by denervated Schwann cells and macrophages. We have shown previously that an injury to sciatic nerves activates erbB2 in the distal myelinating Schwann cells as early as $10 \mathrm{~min}$ and that the receptor activation is required for the myelin breakdown. Although the mechanism of erbB2 activation still remains unknown, the appearance of the receptor activity is in good accord with the observed p38 MAPK activation, suggesting that erbB2 may act as an upstream activator. Supporting this, we show that p38 MAPK mediates Schwann cell demyelination induced by neuregulin, an erbB ligand. Involvement of other receptor tyrosine kinases signaling is also a possibility. For example, FGF-2 and the receptor signaling has been implicated in mediating the Schwann cell response during Wallerian degeneration (Grothe et al., 2000, 2001). Furthermore, our data show that FGF-2 initiates demyelination through activation of the p38 MAPK pathway. Alternately, non-growth factor signals could play a role in inducing the Schwann cell injury response. For instance, calcium influx into the Schwann cells, which occurs immediately following injury, has been suggested as an initiation mechanism for demyelination (Smith and Hall, 1988). In other cell types, calcium-dependent p38 MAPK activation has been reported (Katz et al., 2006; Gee et al., 2007; Guo et al., 2008).

Our data also support the notion that p38 MAPK plays a role in sustaining the denervated state of Schwann cells and the immature state of developing cells. We show that enforced activation of p38 MAPK is sufficient to induce demyelination and drive the differentiated Schwann cells to the denervated phenotype. Conversely, inhibition of the kinase activity prevents Schwann cell dedifferentiation after losing contact with the axons. This is reminiscent of the role of c-Jun, a transcription factor that is associated with immature Schwann cells and strongly expressed in distal Schwann cells following injury (Parkinson et al., 2008). In the absence of c-Jun, distal Schwann cell demyelination is delayed. Furthermore, inhibition of c-Jun blocks Schwann cell differentiation in vitro. Therefore, it is possible that p38 MAPK and c-Jun may function within the same pathway to regulate the denervated and immature state of the Schwann cells. Supporting this, our data show that ectopic activation of p38 MAPK in differentiated Schwann cells is sufficient to induce c-Jun expression (Fig. 5) and promote dedifferentiation.

p38 MAPK is unlikely the sole mediator of injury signal that regulates Schwann cell plasticity in adult nerves. We have shown previously that nerve injury activates Erk1/2, another member of the MAPK family, as early as $20 \mathrm{~min}$ in the distal Schwann cells (Guertin et al., 2005). Although the in vivo function during Wallerian degeneration has not been elucidated, studies in vitro suggest that the Ras/Raf/Erk pathway plays a role in promoting Schwann cell demyelination and dedifferentiation (Harrisingh et al., 2004; Ogata et al., 2004). The mechanism by which multiple signaling pathways activated by injury or growth factor signal cooperate to regulate Schwann plasticity remains to be elucidated. Cross-signaling between the p38 MAPK and the Ras/Raf/ 
Erk pathways has been demonstrated in other cell types. For example, in PC12 cells, Mek1, an upstream activator of Erk1/2, induces neuronal differentiation through activation of p38 MAPK (Morooka and Nishida, 1998). In fibroblasts, p38 MAPK mediates cell senescence induced by oncogenic Ras (Wang et al., 2002).

In developing peripheral nerves, p38 MAPK activity decreases postnatally coinciding with the onset of the myelin program. The function of p38 MAPK associated with immature state of Schwann cells suggests that the postnatal decrease in the kinase activity may be necessary for the Schwann cells to transit into the myelinated phenotype. In accordance with the hypothesis, our data indicate that $\mathrm{p} 38 \mathrm{MAPK}$ acts as a negative regulator of the myelin program. We show that enforced activation of p38 MAPK in Schwann cells blocks cAMP-induced Schwann cell differentiation and inhibits expression of myelin protein including Krox 20. Furthermore, inhibition of the kinase activity in cocultures promotes myelin formation. The mechanism by which p38 MAPK suppresses differentiation and myelination remains to be elucidated. In other systems, p38 MAPK regulates expression of lineage-specific transcription factors or genes that play important roles during development. For example, in skeletal muscle, p38 MAPK regulates myogenesis by modulating the expression and activities of musclespecific transcription factors $\mathrm{MyoD}$ and MEF2 (Keren et al., 2006). In adipocytes, p38 MAPK negatively regulate transcriptional activity of NFATc4 that promote adipogenesis (Yang et al., 2002). A recent study showed that NFATc4 synergize with Sox 10 to activate Krox 20 in Schwann cells (Kao et al., 2009). Therefore, it is possible that p38 MAPK opposes myelination by negatively modulating the activity of NFATc4 and Krox 20. Alternatively, p38 MAPK-induced c-Jun (Fig. 5) may directly antagonize Krox 20 expression (Parkinson et al., 2008).

In addition to its role in regulating myelination, p38 MAPK has also been shown to modulate earlier stages of the Schwann cell-axon interaction. In Schwann cell-DRG coculture, myelination is initiated by the addition of ascorbic acid, which promotes the extracellular matrix assembly required for establishing proper Schwann cell-axon interaction, a process prerequisite for myelination. Fragoso et al. (2003) showed that inhibition of p38 MAPK disrupts laminin-induced Schwann cell alignment along the axons, thus resulting in failed myelination. The study also showed that p38 MAPK inhibition was effective in blocking myelin gene expression only when the inhibitor was added at the time of the ascorbic acid treatment. By delaying SB203580 treatment for few
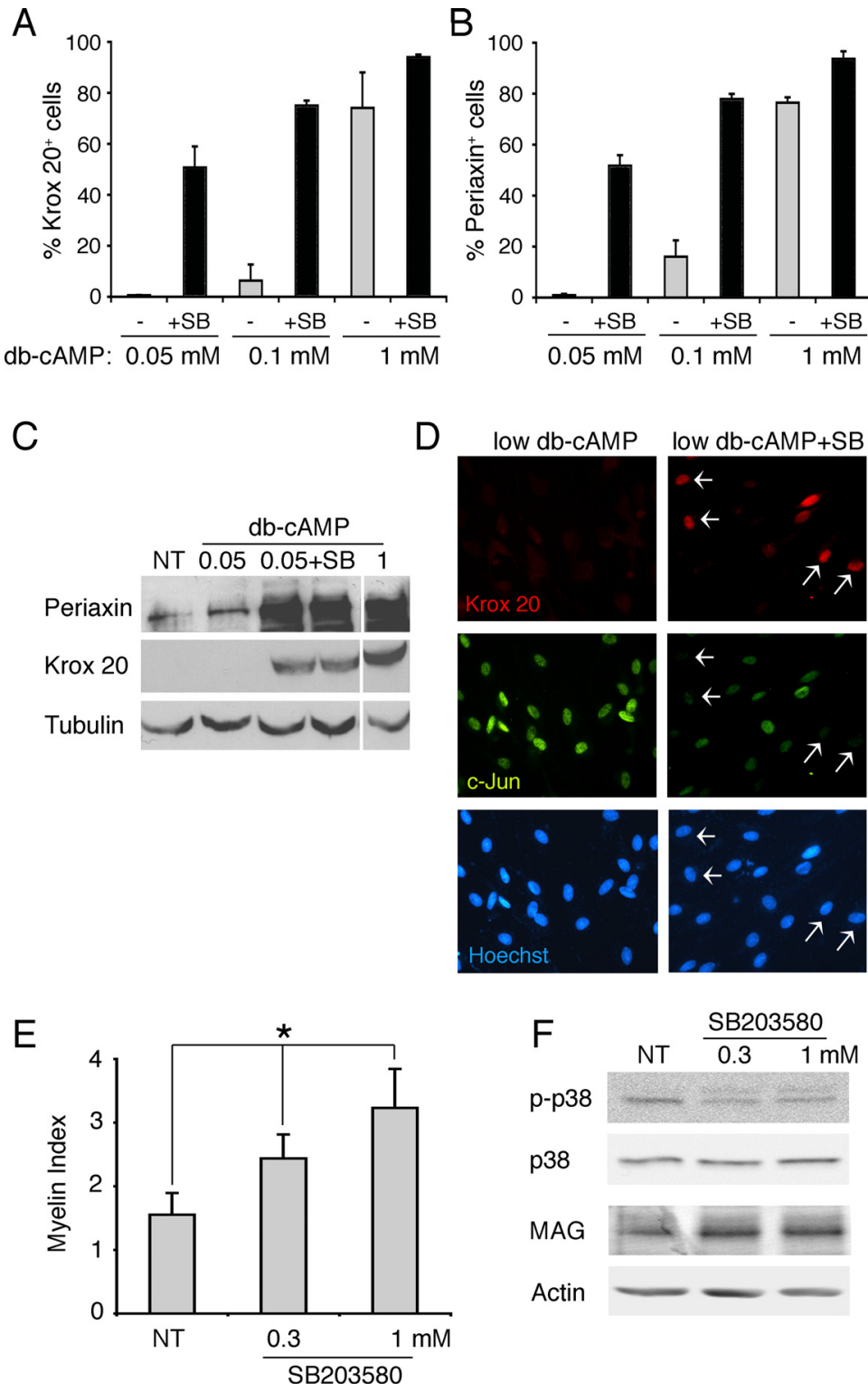

Figure 7. Inhibition of $\mathrm{p} 38 \mathrm{MAPK}$ promotes $S$ chwann cell differentiation and myelination. $A, B$, respectively shows the percentages of Krox 20-positive $(\boldsymbol{A})$ and periaxin-positive $(\boldsymbol{B})$ cells in Schwann cell cultures treated with $0.05,0.1$, and $1 \mu \mathrm{m} \mathrm{db}$-CAMP in the presence (+SB, black bars) or in the absence (-, gray bars) of SB203580 $(10 \mu \mathrm{M})$. C, Expression levels of Krox 20 and periaxin in Schwann cell cultures treated low db-CAMP $(0.05 \mu \mathrm{m})$ with or without SB203580. No treatment (NT) and $1 \mu \mathrm{m} \mathrm{db}$-cAMP serve as the negative and positive controls, respectively. D, Double immunostaining for Krox 20 and c-Jun was performed on Schwann cell cultures under low doses of db-cAMP $(0.05 \mu \mathrm{m})$ with or without SB203580. Treatment with SB203580 increased the number of Krox 20-positive Schwann cells (arrows), which were mostly c-Jun negative. The cells nuclei were visualized by Hoechst staining. $E$, Schwann cell-DRG cocultures were treated with SB203580 (0.3 and $1 \mu \mathrm{m})$ beginning on the third day after initiating myelination. Six to seven days later, cultures were immunostained for MBP and myelination was assessed as we described previously (see also Materials and Methods) (Syed et al., 2010). Inhibition of p38 MAPK increased myelination in a dose-dependent manner. ${ }^{*} p<0.001$. $F$, Western blot analysis on the myelinating cocultures shown in D. SB203580 inhibits the endogenous 38 MAPK activity when added 3 dafter initiating myelination. The increase in myelination was accompanied by an increase in MAG levels in cocultures.

Table 1. Average length of myelin segments in control and SB203580-treated cocultures

\begin{tabular}{|c|c|c|c|c|c|c|}
\hline & \multicolumn{2}{|c|}{ Experiment I } & \multicolumn{2}{|c|}{ Experiment II } & \multicolumn{2}{|c|}{ Experiment III } \\
\hline & Control & SB203580 & Control & SB203580 & Control & SB203580 \\
\hline Myelin segment length ( $\mu \mathrm{m})$ & 166.37 & 184.50 & 152.41 & 167.87 & 103.84 & 116.04 \\
\hline SEM & 2.26 & 2.02 & 2.17 & 1.98 & 1.21 & 1.44 \\
\hline $\begin{array}{l}\text { Number of segments analyzed } \\
\text { Increase over control }(\%)^{*}\end{array}$ & $\begin{array}{l}589 \\
10.89\end{array}$ & 736 & $\begin{array}{l}535 \\
10.14\end{array}$ & 639 & $\begin{array}{l}599 \\
11.7\end{array}$ & 634 \\
\hline
\end{tabular}

Schwann cell-DRG cocultures were treated with SB203580 (1 $\mu \mathrm{M}) 3 \mathrm{~d}$ after initiating myelination. Six to seven days later, cultures were immunostained for MBP, and the lengths of individual myelin segments were measured. Data were collected from four to five cultures per condition per experiment. For each experiment, the average myelin segment lengths between control and SB203580 cultures were significantly different. ${ }^{*} p<0.001$. 
days, we tried to circumvent the inhibitory effect on the earlier Schwann cell-axon interaction and showed that blocking p38 MAPK activity promoted myelination: evidence that p38 MAPK acts as a negative regulator of myelination. These results suggest that p38 MAPK elicits a stage-specific function during Schwann cell myelination.

The function of $\mathrm{p} 38 \mathrm{MAPK}$ as a negative regulator of Schwann cell differentiation and myelination is distinct from the role it plays in oligodendrocytes. In oligodendrocyte progenitor cell cultures, inhibition of p38 MAPK attenuates growth factorinduced lineage progression and maturation into oligodendrocytes (Baron et al., 2000; Fragoso et al., 2007). The kinase also enhances promoter activities MBP and Sox10, a transcription factor required for oligodendrocyte development (Chew et al., 2010). The opposing roles that p38 MAPK plays during Schwann cell and oligodendrocyte differentiation emphasizes the differences in the regulatory mechanisms that governs myelination in the PNS and the CNS.

The abilities of p38 MAPK to trigger demyelination and to promote denervated Schwann cell phenotype implicate that the aberrant activation of the kinase and the cytoplasmic effectors may underlie a wide range of demyelinating disorders in the PNS. Elucidating the p38 MAPK function under the pathological conditions may provide insights into developing therapeutic strategies in treating PNS neuropathies.

\section{References}

Baron W, Metz B, Bansal R, Hoekstra D, de Vries H (2000) PDGF and FGF-2 signaling in oligodendrocyte progenitor cells: regulation of proliferation and differentiation by multiple intracellular signaling pathways. Mol Cell Neurosci 15:314-329.

Bhat NR, Zhang P, Mohanty SB (2007) p38 MAP kinase regulation of oligodendrocyte differentiation with CREB as a potential target. Neurochem Res 32:293-302.

Brockes JP, Fields KL, Raff MC (1979) Studies on cultured rat Schwann cells. I. Establishment of purified populations from cultures of peripheral nerve. Brain Res 165:105-118.

Campenot RB (1982) Development of sympathetic neurons in compartmentalized cultures. II. Local control of neurite survival by nerve growth factor. Dev Biol 93:13-21.

Campenot RB, Martin G (2001) Construction and use of compartmented cultures for studies of cell biology of neurons. In: Protocols for neural cell culture, Ed 3 (Fedoroff S, Richardson A, eds), pp 49-57. Totowa, NJ: Humana.

Chew LJ, Coley W, Cheng Y, Gallo V (2010) Mechanisms of regulation of oligodendrocyte development by p38 mitogen-activated protein kinase. J Neurosci 30:11011-11027.

Costantini TW, Peterson CY, Kroll L, Loomis WH, Eliceiri BP, Baird A, Bansal V, Coimbra R (2009) Role of p38 MAPK in burn-induced intestinal barrier breakdown. J Surg Res 156:64-69.

Cuenda A, Rouse J, Doza YN, Meier R, Cohen P, Gallagher TF, Young PR, Lee JC (1995) SB 203580 is a specific inhibitor of a MAP kinase homologue which is stimulated by cellular stresses and interleukin-1. FEBS Lett 364:229-233.

Davis JB, Stroobant P (1990) Platelet-derived growth factors and fibroblast growth factors are mitogens for rat Schwann cells. J Cell Biol 110:1353-1360.

Eldridge CF, Bunge MB, Bunge RP, Wood PM (1987) Differentiation of axon-related Schwann cells in vitro. I. Ascorbic acid regulates basal lamina assembly and myelin formation. J Cell Biol 105:1023-1034.

Enslen H, Raingeaud J, Davis RJ (1998) Selective activation of p38 mitogenactivated protein (MAP) kinase isoforms by the MAP kinase kinases MKK3 and MKK6. J Biol Chem 273:1741-1748.

Enslen H, Brancho DM, Davis RJ (2000) Molecular determinants that mediate selective activation of p38 MAP kinase isoforms. EMBO J 19:1301-1311.

Escott KJ, Belvisi MG, Birrell MA, Webber SE, Foster ML, Sargent CA (2000) Effect of the p38 kinase inhibitor, SB 203580, on allergic airway inflammation in the rat. Br J Pharmacol 131:173-176.
Esper RM, Loeb JA (2004) Rapid axoglial signaling mediated by neuregulin and neurotrophic factors. J Neurosci 24:6218-6227.

Fragoso G, Robertson J, Athlan E, Tam E, Almazan G, Mushynski WE (2003) Inhibition of p38 mitogen-activated protein kinase interferes with cell shape changes and gene expression associated with Schwann cell myelination. Exp Neurol 183:34-46.

Fragoso G, Haines JD, Roberston J, Pedraza L, Mushynski WE, Almazan G (2007) p38 mitogen-activated protein kinase is required for central nervous system myelination. Glia 55:1531-1541.

Gee K, Angel JB, Mishra S, Blahoianu MA, Kumar A (2007) IL-10 regulation by HIV-Tat in primary human monocytic cells: involvement of calmodulin/calmodulin-dependent protein kinase-activated p38 MAPK and Sp-1 and CREB-1 transcription factors. J Immunol 178:798-807.

Gillespie CS, Sherman DL, Blair GE, Brophy PJ (1994) Periaxin, a novel protein of myelinating Schwann cells with a possible role in axonal ensheathment. Neuron 12:497-508.

Grothe C, Heese K, Meisinger C, Wewetzer K, Kunz D, Cattini P, Otten U (2000) Expression of interleukin-6 and its receptor in the sciatic nerve and cultured Schwann cells: relation to $18-\mathrm{kD}$ fibroblast growth factor-2. Brain Res 885:172-181.

Grothe C, Meisinger C, Claus P (2001) In vivo expression and localization of the fibroblast growth factor system in the intact and lesioned rat peripheral nerve and spinal ganglia. J Comp Neurol 434:342-357.

Guertin AD, Zhang DP, Mak KS, Alberta JA, Kim HA (2005) Microanatomy of axon/glial signaling during Wallerian degeneration. J Neurosci 25:3478-3487.

Guo L, Urban JF, Zhu J, Paul WE (2008) Elevating calcium in Th2 cells activates multiple pathways to induce IL-4 transcription and mRNA stabilization. J Immunol 181:3984-3993.

Harrisingh MC, Perez-Nadales E, Parkinson DB, Malcolm DS, Mudge AW, Lloyd AC (2004) The Ras/Raf/ERK signalling pathway drives Schwann cell dedifferentiation. EMBO J 23:3061-3071.

Jessen KR, Brennan A, Morgan L, Mirsky R, Kent A, Hashimoto Y, Gavrilovic J (1994) The Schwann cell precursor and its fate: a study of cell death and differentiation during gliogenesis in rat embryonic nerves. Neuron 12:509-527.

Jin SX, Zhuang ZY, Woolf CJ, Ji RR (2003) p38 mitogen-activated protein kinase is activated after a spinal nerve ligation in spinal cord microglia and dorsal root ganglion neurons and contributes to the generation of neuropathic pain. J Neurosci 23:4017-4022.

Kao SC, Wu H, Xie J, Chang CP, Ranish JA, Graef IA, Crabtree GR (2009) Calcineurin/NFAT signaling is required for neuregulin-regulated Schwann cell differentiation. Science 323:651-654.

Katz S, Boland R, Santillán G (2006) Modulation of ERK $1 / 2$ and p38 MAPK signaling pathways by ATP in osteoblasts: involvement of mechanical stress-activated calcium influx, PKC and Src activation. Int J Biochem Cell Biol 38:2082-2091.

Keren A, Tamir Y, Bengal E (2006) The p38 MAPK signaling pathway: a major regulator of skeletal muscle development. Mol Cell Endocrinol 252:224-230

Kim SY, Bae JC, Kim JY, Lee HL, Lee KM, Kim DS, Cho HJ (2002) Activation of p38 MAP kinase in the rat dorsal root ganglia and spinal cord following peripheral inflammation and nerve injury. Neuroreport 13:2483-2486.

Morooka T, Nishida E (1998) Requirement of p38 mitogen-activated protein kinase for neuronal differentiation in PC12 cells. J Biol Chem 273:24285-24288.

Myers RR, Sekiguchi Y, Kikuchi S, Scott B, Medicherla S, Protter A, Campana WM (2003) Inhibition of p38 MAP kinase activity enhances axonal regeneration. Exp Neurol 184:606-614.

Ogata T, Iijima S, Hoshikawa S, Miura T, Yamamoto S, Oda H, Nakamura K, Tanaka S (2004) Opposing extracellular signal-regulated kinase and Akt pathways control Schwann cell myelination. J Neurosci 24:6724-6732.

Parkinson DB, Dong Z, Bunting H, Whitfield J, Meier C, Marie H, Mirsky R, Jessen KR (2001) Transforming growth factor $\beta$ (TGF $\beta$ ) mediates Schwann cell death in vitro and in vivo: examination of c-Jun activation, interactions with survival signals, and the relationship of TGF $\beta$-mediated death to Schwann cell differentiation. J Neurosci 21:8572-8585.

Parkinson DB, Bhaskaran A, Droggiti A, Dickinson S, D'Antonio M, Mirsky R, Jessen KR (2004) Krox-20 inhibits Jun-NH2-terminal kinase/c-Jun to control Schwann cell proliferation and death. J Cell Biol 164:385-394. Parkinson DB, Bhaskaran A, Arthur-Farraj P, Noon LA, Woodhoo A, Lloyd 
AC, Feltri ML, Wrabetz L, Behrens A, Mirsky R, Jessen KR (2008) c-Jun is a negative regulator of myelination. J Cell Biol 181:625-637.

Paul A, Wilson S, Belham CM, Robinson CJ, Scott PH, Gould GW, Plevin R (1997) Stress-activated protein kinases: activation, regulation and function. Cell Signal 9:403-410.

Shin KJ, Wall EA, Zavzavadjian JR, Santat LA, Liu J, Hwang JI, Rebres R, Roach T, Seaman W, Simon MI, Fraser ID (2006) A single lentiviral vector platform for microRNA-based conditional RNA interference and coordinated transgene expression. Proc Natl Acad Sci U S A 103:13759-13764.

Smith KJ, Hall SM (1988) Peripheral demyelination and remyelination initiated by the calcium-selective ionophore ionomycin: in vivo observations. J Neurol Sci 83:37-53.

Syed N, Reddy K, Yang DP, Taveggia C, Salzer JL, Maurel P, Kim HA (2010) Soluble neuregulin-1 has bifunctional, concentration-dependent effects on Schwann cell myelination. J Neurosci 30:6122-6131.

Tofaris GK, Patterson PH, Jessen KR, Mirsky R (2002) Denervated Schwann cells attract macrophages by secretion of leukemia inhibitory factor (LIF) and monocyte chemoattractant protein-1 in a process regulated by interleukin-6 and LIF. J Neurosci 22:6696-6703.
Wang W, Chen JX, Liao R, Deng Q, Zhou JJ, Huang S, Sun P (2002) Sequential activation of the MEK-extracellular signal-regulated kinase and MKK3/6-p38 mitogen-activated protein kinase pathways mediates oncogenic ras-induced premature senescence. Mol Cell Biol 22:3389-3403.

Yamazaki T, Sabit H, Oya T, Ishii Y, Hamashima T, Tokunaga A, Ishizawa S, Jie S, Kurashige Y, Matsushima T, Furuta I, Noguchi M, Sasahara M (2009) Activation of MAP kinases, Akt and PDGF receptors in injured peripheral nerves. J Peripher Nerv Syst 14:165-176.

Yang TT, Xiong Q, Enslen H, Davis RJ, Chow CW (2002) Phosphorylation of NFATc4 by p38 mitogen-activated protein kinases. Mol Cell Biol 22:3892-3904.

Zanazzi G, Einheber S, Westreich R, Hannocks MJ, Bedell-Hogan D, Marchionni MA, Salzer JL (2001) Glial growth factor/neuregulin inhibits Schwann cell myelination and induces demyelination. J Cell Biol 152:1289-1299.

Zrouri H, Le Goascogne C, Li WW, Pierre M, Courtin F (2004) The role of MAP kinases in rapid gene induction after lesioning of the rat sciatic nerve. Eur J Neurosci 20:1811-1818. 